\title{
PENGEMBANGAN MEDIA PEMBELAJARAN MONOPOLI PADA MATERI SISTEM PENCERNAAN DI SMP
}

\author{
Khalida Ulfa $^{1) a}$, Lia Rozalina ${ }^{1)}$ \\ 1)Pendidikan Biologi Fakultas Ilmu Tarbiyah dan Keguruan UIN Raden Fatah Palembang, \\ Jl.Prof. K.H. Zainal Abidin Fikri No 1A KM 3.5, Palembang 30126, Indonesia \\ ${ }^{a)}$ khalidabio_uin@radenfatah.ac.id \\ Telp: +62-812-7865-5547
}

\begin{abstract}
This research was aims to developed, feasibility and compare differences in learning out-comes before and after used Monopoly Games Smart (MGS) learning media on digestive system topic in junior high school IBA Palembang. Research applies Research and Development methods with steps, namely define, design, and development. Egibility was based on the evaluation of media expert and small scale trials. Data collection in this study used interviews, questionnaire and documentation. Analysis tehonique were including analysis of product data.. The results show that the Monopoly Games Smart (MGS) learning media has significant effect in improving the mastery of concept. Based on students mastery of concept showed that the implementation of learning using Monopoly Games Smart (MGS) is better than convensional. The learning process in the digestive system topic is more effective and student centered which makes students more active in learning and makes the learning process more meaningful. If the learning response is good, mastery of the concept will be good.
\end{abstract}

Keywords: Monopoly Games Smart (MGS), learning media, Digestive system

\begin{abstract}
ABSTRAK
Penelitian ini bertujuan untuk mengembangkan, kelayakan dan membandingkan perbedaan hasil belajar sebelum dan sesudah menggunakan media pembelajaran Monopoly Games Smart (MGS) pada topik sistem pencernaan di SMP IBA Palembang. Penelitian menerapkan metode Penelitian dan Pengembangan dengan langkah-langkah, yaitu pendefinisian, desain, dan pengembangan. Egibilitas didasarkan pada evaluasi ahli media dan uji coba skala kecil. Pengumpulan data dalam penelitian ini menggunakan wawancara, kuesioner dan dokumentasi. Teknik analisis meliputi analisis data produk. Hasil penelitian menunjukkan bahwa media pembelajaran Monopoly Games Smart (MGS) berpengaruh signifikan dalam meningkatkan penguasaan konsep. Berdasarkan penguasaan konsep siswa menunjukkan bahwa penerapan pembelajaran menggunakan Monopoly Games Smart (MGS) lebih baik daripada konvensional. Proses pembelajaran pada materi sistem pencernaan dirasakan lebih efektif dan berpusat pada siswa yang membuat siswa lebih aktif dalam pembelajaran dan membuat proses belajar menjadi lebih bermakna. Apabila respon pembelajaran baik, maka pemahaman konsep tentang materi juga akan baik.
\end{abstract}

Kata kunci: Monopoly Games Smart (MGS), Media pembelajaran, Sistem pencernaan 


\section{PENDAHULUAN}

Pendidikan merupakan usaha sadar manusia untuk mengembangkan dan membina harkat serta martabat secara menyeluruh supaya menjadi lebih baik (Kemendikbud, 2016). Tujuan dari pendidikan yaitu suatu proses membangun manusia menjadi lebih cerdas, merubah sikap, nilai, pemahaman, dan memiliki ilmu pengetahuan. Pendidikan juga dapat mengembangkan semua aspek-aspek rohani, jasmani aspek mental, spiritual, fisik atau aspek-aspek kognitif, efektif, psikomotor, bukan salah satu aspek atau beberapa aspek saja (Yusuf, 2015).

Menurut Wijaya, $d k k$ (2016) saat ini tuntutan pendidikan mengarah pada abad ke-21 yang artinya mengalami perubahan-perubahan dari waktu sebelumnya. Hal ini terlihat dari proses pembelajaran yang lebih kooperatif, inovatif, dan modern. Salah satu upaya dalam menghadapi tuntutan pendidikan abad 21 yaitu guru harus mampu memiliki kompetensi dalam menciptakan media pembelajaran, model pembelajaran, strategi pembelajaran dan lain-lain. Hal tersebut dilakukan supaya guru memiliki kemampuan dalam meningkatkan pemahaman serta hasil belajar siswa (Rustaman, 2005). Selain itu, guru mampu menciptakan sesuatu hal yang lebih menarik dalam menunjang proses kegiatan belajar mengajar.

Berdasarkan hasil wawancara yang telah dilakukan dengan guru dan siswa di salah satu sekolah SMP swasta Palembang, dari seluruh konten pelajaran IPA yang dirasakan sulit yaitu pada pelajaran Biologi karena masih bersifat abstrak. Pelajaran biologi dianggap sulit karena guru ketika mengajar masih menggunakan metode konvensional seperti menggunakan metode ceramah, diskusi, dan tanpa melibatkan media pembelajaran. Kurangnya media pembelajaran yang digunakan karena fasilitas dari sekolah yang kurang lengkap, hal tersebut menyebabkan nilai siswa masih berada di bawah nilai kriteria ketuntasan minimum (KKM) yaitu 70 yang ditentukan oleh sekolah. Selain itu juga kurangnya kreativitas guru dalam mendesain media pembelajaran di kelas menyebabkan siswa menjadi jenuh dan tidak termotivasi dalam mengikuti pembelajaran. Serta penyebab lainnya adalah pelajaran Biologi yang masih terpaku pada buku yang menyebabkan siswa menjadi tidak aktif sehingga masih banyak siswa yang kurang memahami pelajaran.

Pada pelajaran Biologi, materimateri seperti sistem pencernaan, sistem pernapasan, sistem peredaran darah merupakan materi yang mengandung konsep abstrak sehingga sulit dipahami siswa (Musfiroh, $d k k$ 2012; Masruroh, $d k k$ 2014; Sajerah, 2013, Ulfa, 2017). Materi sistem pencernaan ini memiliki banyak konsep yang bersifat abstrak, banyaknya nama ilmiah Biologi serta salah satu materi yang dianggap penting karena banyak diaplikasikan dalam kehidupan sehari-hari. Hal inilah yang menyebabkan siswa mengalami kesulitan dalam memahaminya yang menyebabkan nilai siswa rendah. Menurut Masruroh dkk (2014), konsep materi yang masih bersifat abstrak dapat menyebabkan siswa mengalami kesulitan dalam memahami materi, hal tersebut juga dapat mempengaruhi keberhasilan siswa dalam mencapai tujuan pembelajaran.

Karakteristik materi sistem pencernaan terdiri atas gambaran dari beberapa fakta yang membentuk pengetahuan konseptual yang kompleks. Pada dasarnya, materi sistem pencernaan mengajak siswa memahami suatu proses pengujian pada zat makanan yang terdapat pada beberapa jenis makanan. Pada setiap uji bahan makanan akan menunjukkan beberapa hasil seperti munculnya warna kebiruan setelah ditetesi lugol atau iodida yang menunjukkan adanya zat karbohidrat pada makanan. Munculnya transparan pada kertas minyak menunjukkan adanya zat makanan yang mengandung lemak, dan munculnya warna ungu setelah ditetesi biuret yang menunjukkan adanya kandungan protein pada makanan (Sutanto, 2013).

Prinsip dari konsep materi sistem pencernaan yang abstrak harus bisa mengarahkan pengetahuan faktual menjadi pengetahuan konseptual. Akan tetapi, kebanyakan guru mengarahkan 
pengetahuan konseptual menjadi faktual sehingga menyebabkan rendahnya pemahaman konsep siswa ( Ulfa, 2017). Upaya yang dapat dilakukan guru dalam menstransformasi pengetahuan konseptual menjadi pengetahuan faktual dapat dilakukan dengan menggunakan media pembelajaran. Dengan karakteristik materi sistem pencernaan tersebut, perlu adanya penggunaan media pembelajaran untuk dapat menghasilkan keberhasilan belajar yang optimal.

Mardia dan Andi (2017) menyatakan bahwa keberhasilan belajar dapat dipengaruhi oleh beberapa faktor salah satunya yaitu dengan menggunakan media pembelajaran yang dapat digunakan sebagai wadah, perantara, dan penyambung pesan pembelajaran. Media yang tepat dan sesuai dapat meningkatkan pengalaman belajar siswa serta dapat membuat siswa lebih semangat dalam belajar. Salah satu media pembelajaran yang dapat menyebabkan siswa bersemangat dalam belajar yaitu media pembelajaran berupa permainan (Agustiya $d k k, 2017)$. Salah satu media pembelajaran berupa permainan yaitu Monopoly Games Smart (MGS). Media monopoli merupakan salah satu media pembelajaran yang menyenangkan. Permainan monopoli ini disesuaikan pada kondisi dan keadaan siswa yang kesehariannya masih suka bermain. Ulfaeni, $d k k$ (2017) menyatakan bahwa karakteristik anak SMP pada dasarnya masih suka bermain sambil belajar. Dengan bermain sambil belajar akan menghasilkan kegiatan belajar lebih menarik dan membantu suasana belajar menjadi lebih menyenangkan. media monopoli ini mampu membangkitkan keinginan dan minat baru serta memotivasi siswa untuk belajar sehingga menyebabkan hasil belajar siswanya juga meningkat. Penggunaan media monopoli ini juga menyenangkan bagi siswa sehingga suasana belajar yang tercipta lebih menyenangkan dan bermakna.

\section{METODELOGI PENELITIAN}

\section{Waktu dan Tempat}

Penelitian ini telah dilaksanakan pada tanggal 08 - 11 April tahun 2019 di kelas eksperimen sesuai dengan Rencana Pelaksanaan Pembelajaran (RPP) yang telah disusun. Penelitian ini dilaksanakan di salah satu SMP swasta di Palembang kelas VIII.

\section{Metode penelitian}

Metode penelitian yang digunakan peneliti adalah metode penelitian dan pengembangan (Research and Development). Model pengembangan yang digunakan dalam penelitian ini adalah model pengembangan Four-D(4-D) yang telah dikembangkan oleh S.Thiagarajan $d k k$ (1974). Model pengembangan Four-D(4-D) terdiri dari empat tahapan yaitu tahap pendefinisian (define), tahap perencanaan (design), tahap pengembangan (develop), dan tahap penyebaran (disseminate) (Murdiyani, 2012). Peneliti hanya melakukan penelitian ini hanya 3 tahap sampai pada tahap pengembangan (develop) karena keterbatasan waktu dan biaya kalau sampai pada tahap penyebaran (disseminate). Penelitian ini bertujuan untuk menghasilkan produk tertentu dan menguji keefektifan produk tersebut. Dalam bidang pendidikan, desain produk dapat langsung diujicobakan setelah divalidasi dan direvisi (Sugiyono, 2015). Pengujian dilakukan dengan tujuan untuk mendapatkan informasi apakah media pembelajaran tersebut efektif.

\section{Prosedur penelitian}

Tahap-tahap dalam penelitian pengembangan ini akan dijelaskan sebagai berikut.

1. Tahap pendefinisian untuk menentukan dan mendefinisikan kebutuhan-kebutuhan di dalam proses pembelajaran berbagai informasi yang berkaitan dengan produk yang akan dikembangkan berdasarkan analisis kebutuhan yang telah dilakukan di salah satu SMP swasta di Palembang. adalah tahap pertama dalam penelitian pengembangan. 
2. Teknik pengumpulan data pada penelitian ini menggunakan wawancara kepada guru biologi kelas VIII terkait materi biologi yang sulit diajarkan dan sampel siswa terkait materi yang sulit dipelajari serta observasi laboratorium di sekolah tersebut.

3. Tahap Design ini mempunyai 3 langkah yang harus dilakukan, yaitu (1) pemilihan media (media selection), (2) pemilihan format (format selection), (3) membuat rancangan awal (initila design) sesuai format yang dipilih (Mulyatiningsih, 2013).

4. Tahap pengembangan (develop) ini digunakan sumber data untuk mengetahui kevalidan media pembelajaran yang dikembangkan melalui validator, dan respon siswa. Teknik pengumpulan data yang digunakan dalam penelitian ini yaitu berupa lembar penilaian berupa lembar penilaian validasi media pembelajaran dan lembar validasi dari ahli.

\section{HASIL DAN PEMBAHASAN}

\section{Tahap pendefinisian (define)}

Dari identifikasi masalah yang telah dilakukan di salah satu sekolah SMP di Palembang, materi yang sulit diajarkan oleh guru dan sulit dipelajari oleh siswa yaitu materi sistem pencernaan pada manusia dan belum adanya laboratorium untuk kegiatan praktikum. Pada materi tersebut guru hanya menggunakan media cartha dan torso. Dalam hal ini penulis mengembangkan sesuatu yang baru di salah satu SMP swasta di Palembang agar bisa meningkatkan pengetahuan siswa.

\section{Tahap perancangan (Design)}

Tahap design ini mempunyai 3 langkah yang harus dilakukan, yaitu (1) pemilihan media (media selection), (2) pemilihan format (format selection), (3) membuat rancangan awal (initila design) sesuai format yang dipilih (Mulyatiningsih, 2013).

Langkah pertama pada tahap design, peneliti memilih media permainan yang sesuai dengan karakteristik siswa SMP yang masih senang bermain. Maka media yang dipilih adalah Monopoly Games Smart (MGS), dimana media pembelajaran ini diharapkan dapat membantu siswa dalam memahami pembelajaran dengan cara permainan.

Langkah kedua dalam pada tahap ini yaitu pemilihan format. Format media yang digunakan mengacu pada format monopoli pada umumnya, hanya saja konten materi di sisipkan pada kolom permainan sesuai indikator pencapaian kompetensi yang dimiliki.

Langkah ketiga yaitu peneliti membuat rancangan awal Monopoly Games Smart (MGS) sesuai format yang telah ditentukan. Sketsa media pembelajaran MGS pembelajaran ini terbagi menjadi dua, yaitu pertama sketsa monopoli tentang zat-zat makanan dan kedua tentang organ-organ dan kelainan pada sistem pencernaan. Adapun salah satu langkah dalam tahap design dapat digambarkan sebagai berikut. 

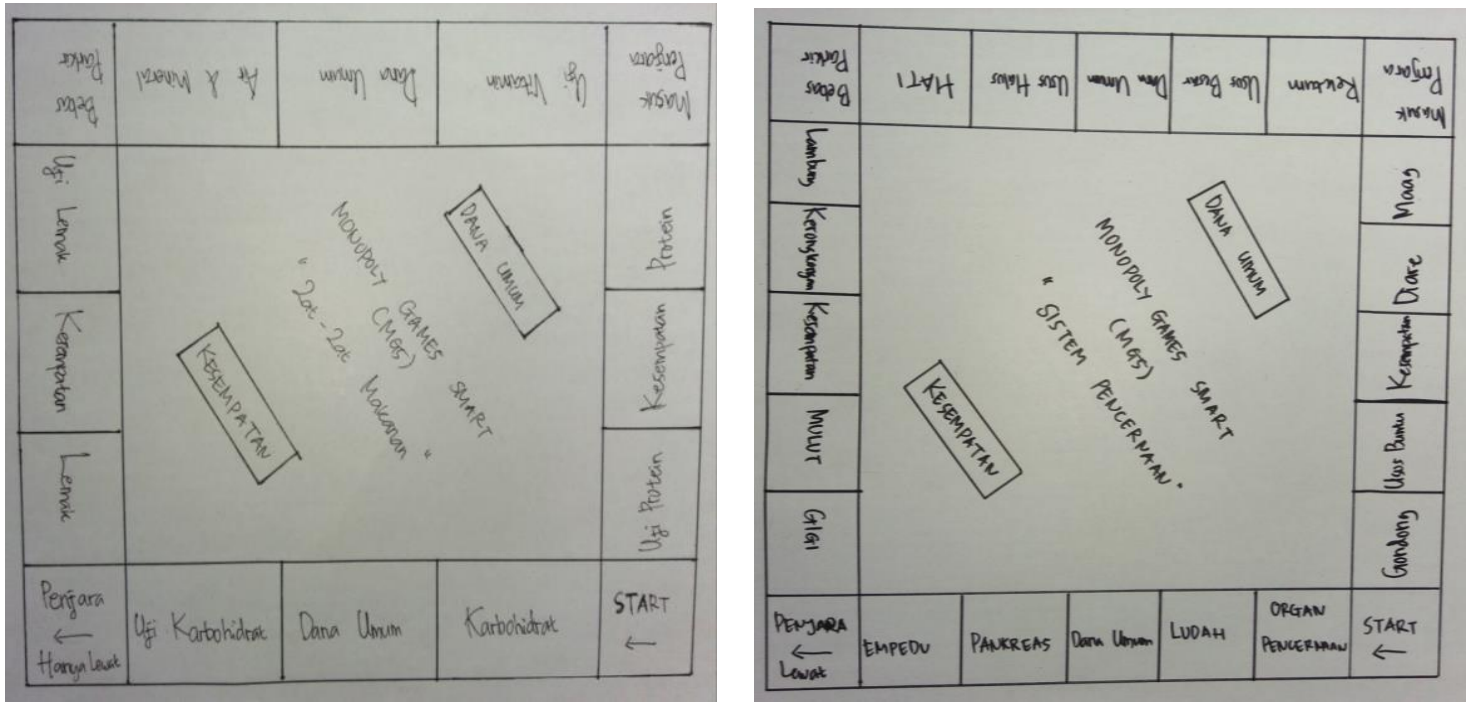

Gambar 1. Sketsa atau rancangan awal Monopoly Games Smart (MGS)

\section{Tahap pengembangan}

Pada tahap pengembangan, sketsa yang telah dibuat kemudian dibentuk menjadi media pembelajaran Monopoly Games Smart (MGS) lengkap dengan seluruh atribut permainan yang biasa digunakan pada permainan monopoli. Selain itu, pada tahap ini juga dibuat Rancangan Pelaksanaan Pembelajaran (RPP) yang dapat memfasilitasi penggunaan media pembelajaran dan buku pedoman permainan yang membantu guru dan siswa memahami cara bermain Monopoly Games Smart (MGS) dalam proses pembelajaran. Untuk mengetahui kevalidan media pembelajaran yang dikembangkan maka dilakukan validasi kepada validator dan angket respon siswa. Adapun gambar media pembelajaran Monopoly Games Smart (MGS) pada tahap pengembangan dapat dilihat pada Gambar 2.

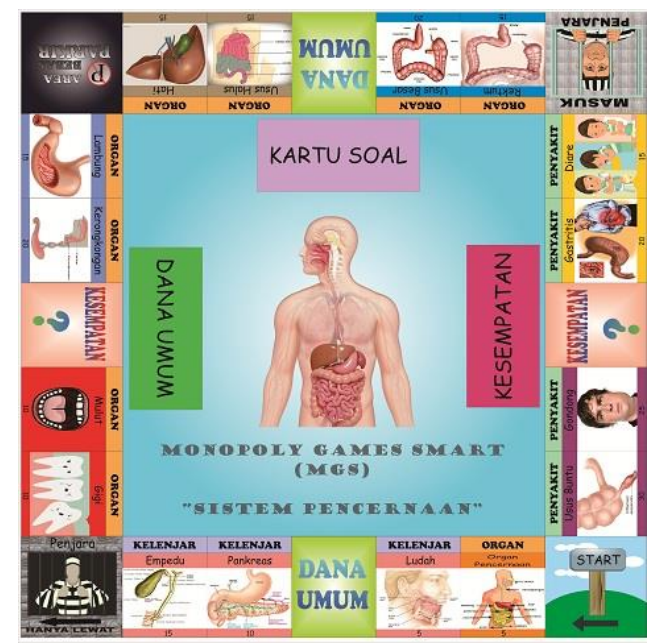

(a)

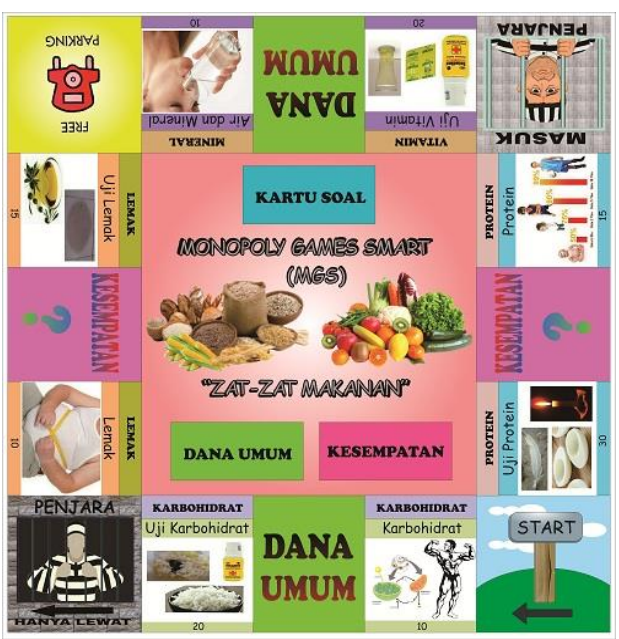

(b) 

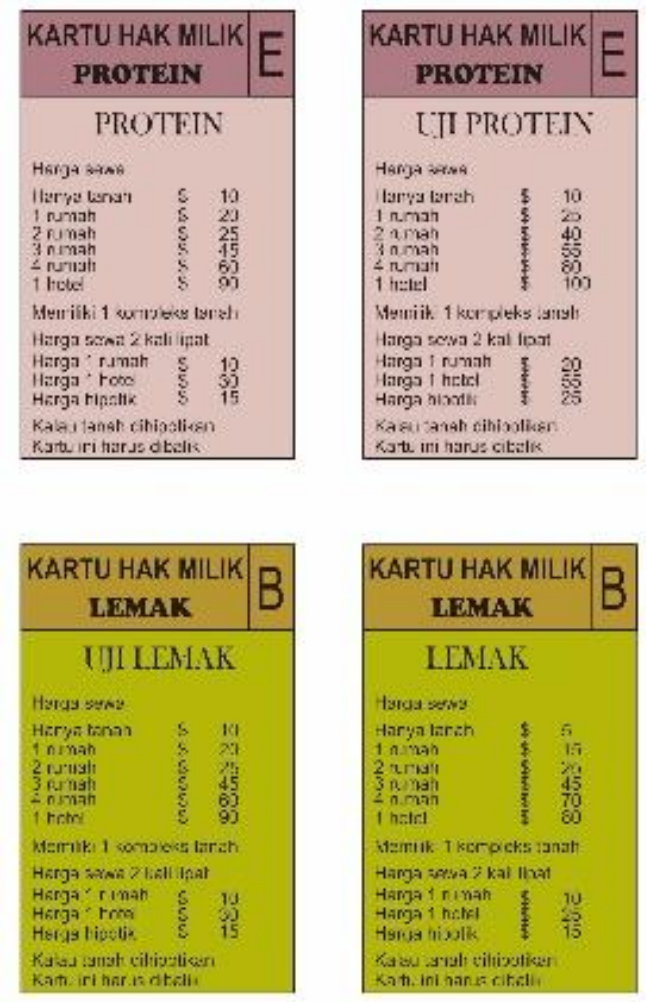
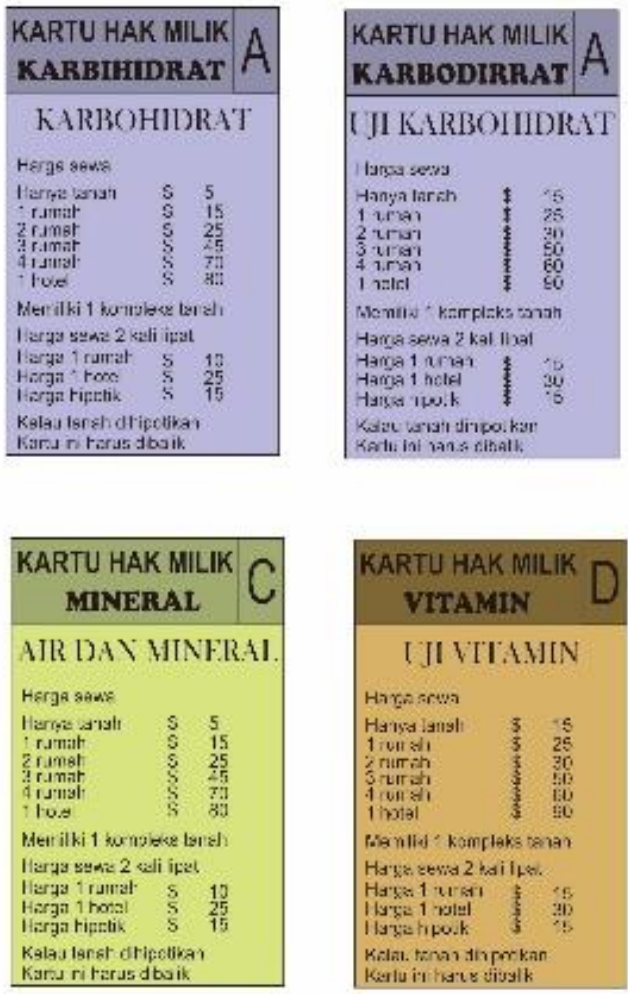

(c)
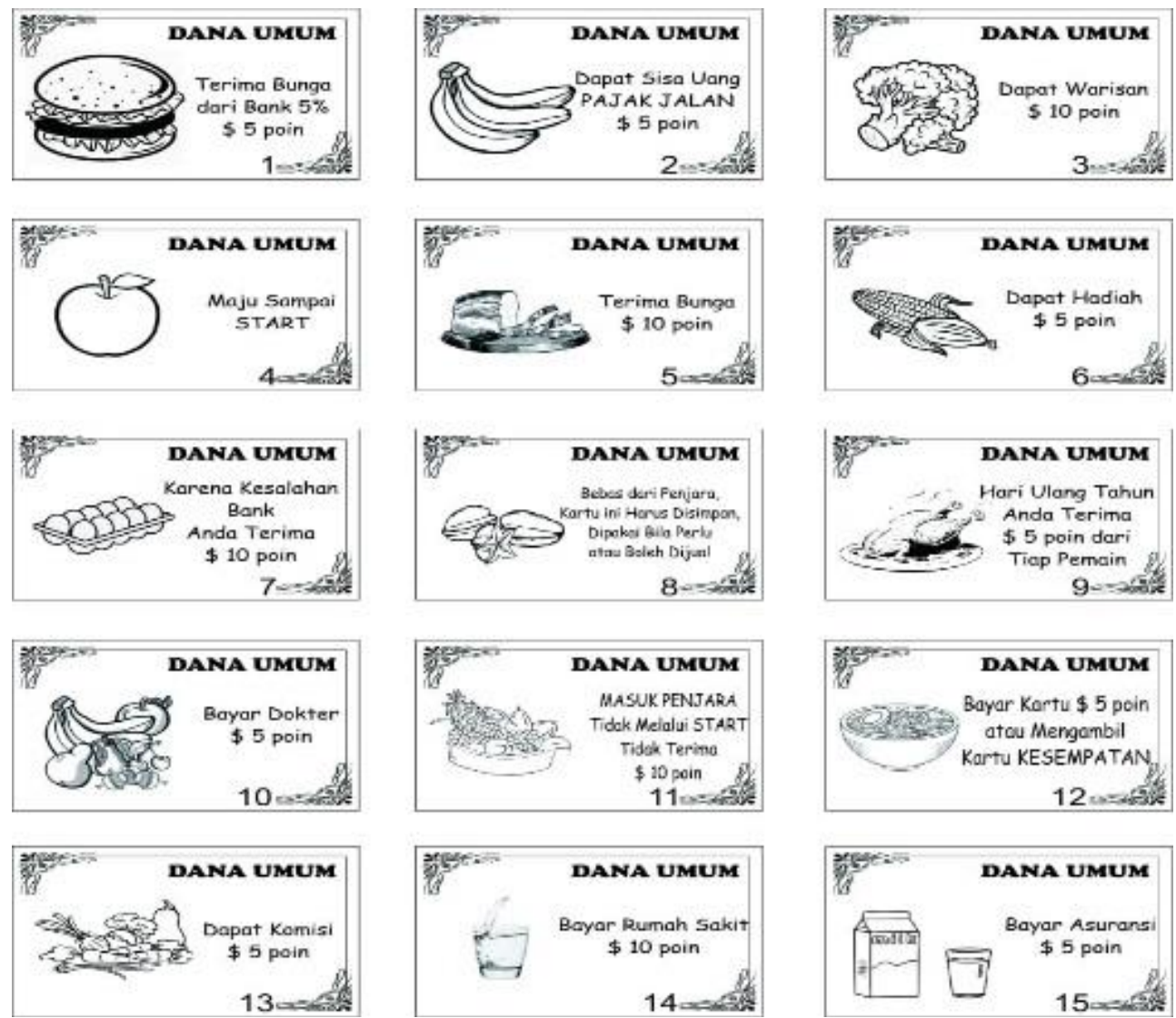

(d)

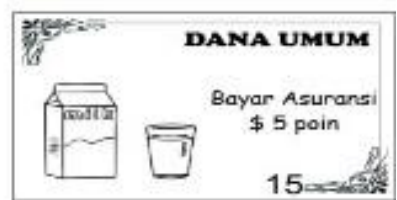



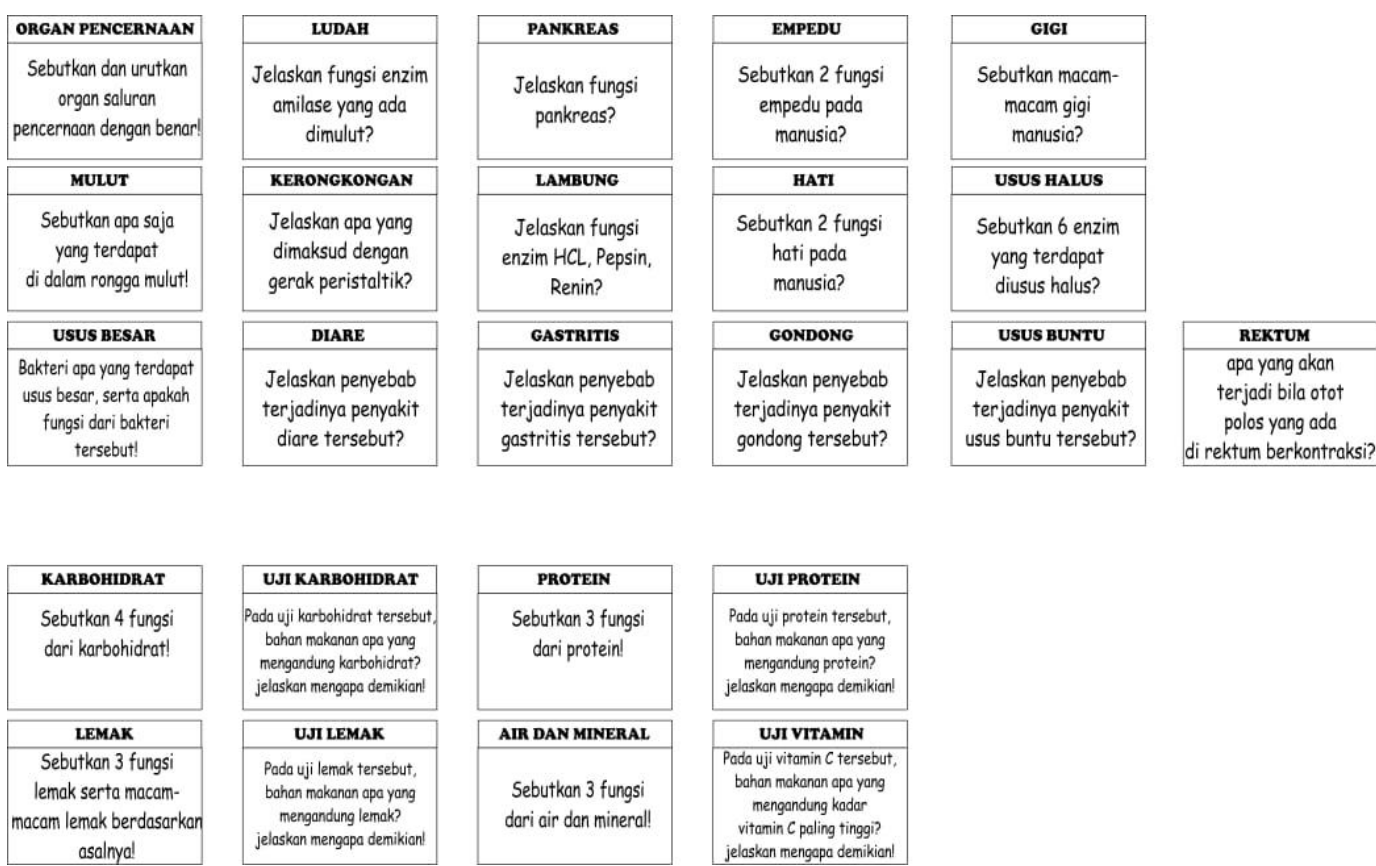

(e)

Gambar 2. Design media pembelajaran Monopoly Games Smart (MGS) yang divalidasi (a. Monopoli organ pencernaan; b. Monopoli zat makanan; c. Kartu hak milik; d. Dana umum; e. Kartu soal).

Media pembelajaran MGS yang telah dibuat sesuai dengan sketsa awal akan divalidasi oleh ahli materi, ahli tampilan (desain) dan ahli bahasa. Validasi materi pada media pembelajaran MGS ini divalidasi oleh ahli pendidikan Biologi dan guru mata pelajaran Biologi. Pendesainan media pembelajaran ini selanjutnya divalidasi oleh ahli media yaitu ahli media pembelajaran. Kemudian, validasi bahasa divalidasi oleh ahli bahasa Indonesia dan guru bahasa Indonesia. Validasi media pembelajaran MGS ini bertujuan untuk mengetahui tingkat kelayakan media MGS yang telah dibuat. Berdasarkan hasil validasi maka di peroleh hasil sebagai berikut.

Tabel 1. Rekapitulasi Hasil Validasi Media Monopoly Games Smart (MGS)

\begin{tabular}{|c|l|c|c|}
\hline No & \multicolumn{1}{|c|}{ Jenis Validasi } & $\begin{array}{c}\text { Persentase } \\
(\boldsymbol{\%})\end{array}$ & Kualifikasi \\
\hline 1 & Validasi ahli materi & $91,07 \%$ & Sangat Layak \\
\hline 2 & Validasi ahli media & $82,14 \%$ & Sangat Layak \\
\hline 3 & Validasi ahli bahasa & $89,58 \%$ & Sangat Layak \\
\hline
\end{tabular}


Berdasarkan Tabel 1, hasil validasi media pembelajaran MGS tersebut menunjukkan kategori sangat layak dan tidak perlu direvisi. Setelah divalidasi, media pembelajaran MGS selanjutnya diujicoba kepada siswa dan guru. Ujicoba implementasi ini dilakukan untuk mengetahui tanggapan, masukan, dan pelaksanaan pembelajaran menggunakan media pembelajaran MGS serta menguji efektivitas media terhadap hasil belajar siswa pada materi sistem pencernaan Berdasarkan angket respon siswa terhadap media pembelajaran MGS didapatkan hasil yang terlihat pada Gambar 3. Hasil respon ini juga dikuatkan dengan hasil belajar siswa yang yang menunjukkan adanya peningkatan pada hasil pre-test dan post-test siswa pada materi sistem pencernaan yang dapat dilihat pada Tabel 2.

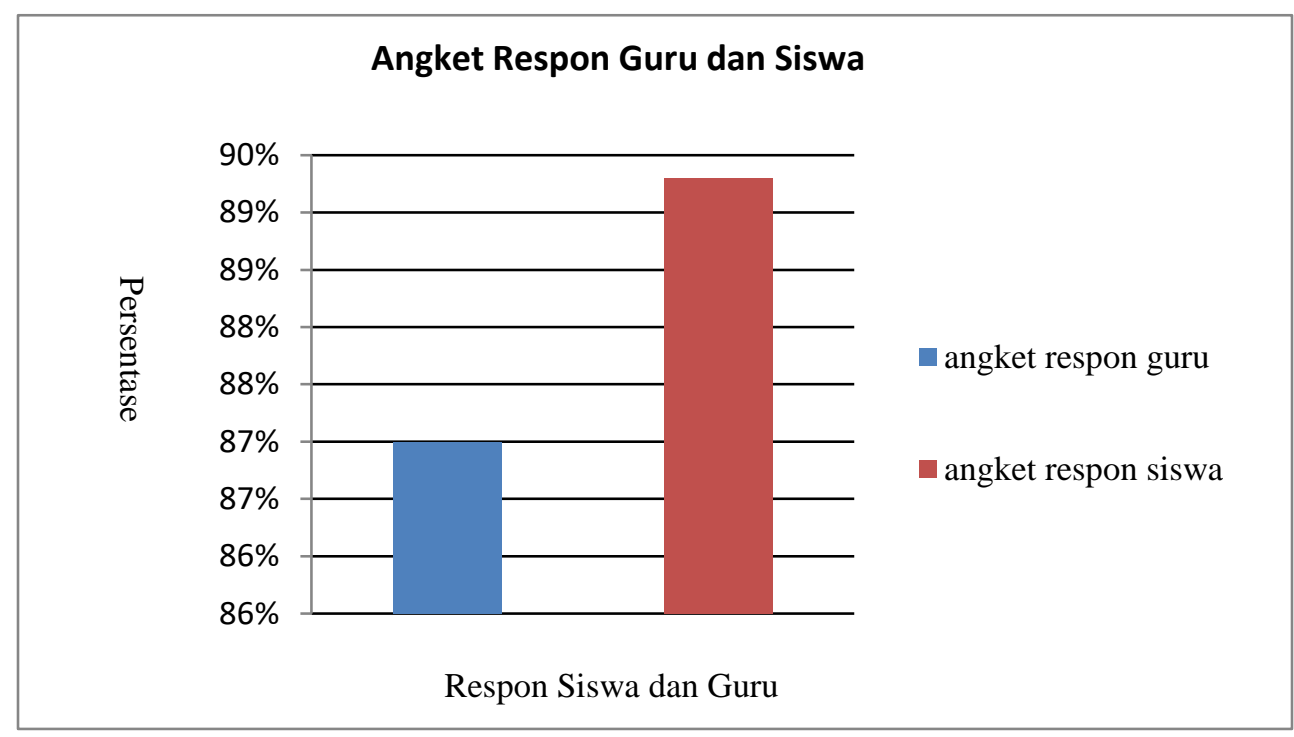

Gambar 3. Angket Respon Guru dan Siswa

Tabel 2. Perbandingan nilai pre-test dan post-test siswa setelah menggunakan media pembelajaran MGS.

\begin{tabular}{|c|c|c|}
\hline Jumlah siswa & Pre-test & Post-test \\
\hline 3 orang & 42,62 & 82,28 \\
\hline 7 orang & 39,96 & 87,70 \\
\hline 30 orang & 38,10 & 81,39 \\
\hline
\end{tabular}

\section{Pembahasan}

Media Pembelajaran MGS adalah suatu media pembelajaran yang dikemas dalam suatu permainan monopoli. Konsep bermain media permainan monopoli biologi diadopsi dari permainan MGS secara umum yang telah memodifikasi peraturan dan menambahkan pertanyaan-pertanyaan yang harus dijawab peserta didik selama mengikuti kegiatan belajar menggunakan media permainan monopoli (Susanto, $d k k$ 2012). Pengembangan media pembelajaran Monopoly Games Smart (MGS) yang digunakan pada penelitian ini dirasakan menarik, menyenangkan, sehingga dapat membuat siswa lebih berpartisipasi dan semangat dalam mengikuti proses pembelajaran. 
Hal ini selaras dengan masukan dan saran dari uji coba skala kecil pada saat pengembangan media pembelajaran MGS diterapkan di skala tersebut.

Hasil penelitian oleh Agustiya $d k k$ (2017); Subroto (2016); menyatakan bahwa penggunaan media pembelajaran monopoli dapat menyebabkan proses pembelajaran siswa menjadi lebih menyenangkan, proses pembelajaran lebih efektif, serta siswa lebih aktif dalam proses belajar mengajar dan proses pembelajaran berpusat pada siswa. Dengan demikian penggunaan media MGS ini dapat membangkitkan minat belajar dan keaktifan siswa untuk belajar yang memungkinkan dapat meningkatkan pemahaman konsep siswa tentang materi.

Permainan monopoli dapat dijadikan sebagai media pembelajaran biologi dengan berbagai komponen dalam MGS yang dapat dimodifikasi sesuai dengan kebutuhan pembelajaran sehingga MGS dapat menjadi media pembelajaran yang tepat dan menyenangkan untuk meningkatkan minat belajar peserta didik (Suitriani, 2016). Menurut Siskawati $d k k$ (2016), penggunaan media pembelajaran monopoli dapat mengakibatkan siswa merasa tertarik, perhatian, berpartisipasi serta memiliki rasa keinginan dalam mengikuti proses pembelajaran yang dapat membangkitkan minat belajar siswa menjadi lebih baik serta siswa lebih termotivasi dalam mengikuti proses pembelajaran. Selain itu juga, dengan menggunakan media monopoli siswa dapat belajar langsung dan mengalami sendiri proses pembelajaran sehingga konsepkonsep materi dapat lebih mudah dipahami oleh siswa. Apabila proses pembelajaran tersebut dilalukan sendiri, maka proses pembelajaran menjadi lebih bermakna dan proses pembelajaran berpusat pada siswa.

Adapun aturan permainan dalam pembelajaran menggunakan media pembelajaran MGS, yaitu.

1. Untuk 5 orang pemain yang dipilih oleh guru secara heterogen berdasarkan jenis kelamin dan kompetensi yang dimiliki siswa.

2. Guru membagikan sebuah papan permainan yang dilengkapi dengan petak-petak

"ORGAN PENCERNAAN, KELENJAR,
PENYAKIT", "DANA UMUM", "KESEMPATAN", dan atribut permainan monopoli yang sudah dimodifikasi.

3. Papan permainan diletakkan di depan kelas yang cukup besar. Kartu DANA UMUM dan KESEMPATAN diletakkan terbalik di dalam petak yang telah tersedia. Tiap pemain pada mulanya diberi poin $\$ 50$. Segala kartu hak milik diserahkan pada bank.

4. Setiap pemain mula-mula diberi poin seharga $\$ 60$, dibagi dalam nilai sebagai berikut: 1 lembar $\$$ 20, 3 lembar \$ 10, dan 2 lembar \$ 5. Sisanya diserahkan kepada bank.

5. Pemain melempar dadu bergiliran, angka yang terbanyak main dahulu. Pemain dimulai dipetak START. Pemain dapat membeli rumah setelah melewati 1 kali putaran. Putaran pertama pemain mengulangi materi sesuai dengan gambar yang telah disediakan.

6. Tiap pemain setelah melewati START diberi gaji \$ 10 dari bank.

7. Bila seorang pemain berhenti di atas TANAH BANGUNAN yang belum dimiliki orang lain, (dengan cara melempar dadu maupun dengan paksaaan kartu KESEMPATAN atau kartu DANA UMUM), pemain tersebut mendapat hak untuk membeli rumah tersebut dengan syarat mampu menjawab pertanyaan yang telah disediakan dengan durasi waktu tidak boleh lebih dari 2 menit dan boleh melihat buku. Setelah mampu menjawab pertanyaan tersebut, pemain mendapatkan kartu hak milik dari bank, dan harus diletakkan terlentang di atas meja.

8. Bila seorang pemain berhenti di tanah rumah yang telah dimiliki pemain lain, dengan perantara dadu maupun karena diharuskan oleh kartu KESEMPATAN dan DANA UMUM, pemilik bangunan 
berhak memungut sewa atas tanah tersebut sesuai dengan tarif poin yang telah ditentukan.

9. Pemain memanggil kartu yang teratas sekali menaati petunjukpetunjuk di dalamnya, kartu tersebut dikembalikan dibawah sendiri. Hanya kartu "KELUAR dari PENJARA" dapat di tahan hingga terpakai atau dijual kepada lawan pemain.

10. Pemain diharuskan masuk penjara karena:

1. Lemparan dadu bijinya berhenti di petak "MASUK PENJARA"

2. Mendapat perintah masuk penjara melalui kartu KESEMPATAN atau DANA UMUM.

Jika pemain masuk penjara ia tidak berhak menerima $\$ 10$ dari bank tiap kitaran. Jika seorang pemain berhenti di petak "PENJARA" karena lemparan dadu, ia tak dipenjarakan namun hanya lewat saja, dan tidak dikenakan hukuman apa-apa.

11. Seorang pemain dapat keluar dari penjara apabila:

1. Memiliki sehelai kartu "KELUAR dari PENJARA" dari pemain lain.

2. Lawan main sudah melewati garis START.

12. Pemain dinyatakan bangkrut dan kalah apabila ia telah kehabisan poin dan rumah yang ia miliki telah digadaikan ke bank.

13. Pemain dinyatakan MENANG apabila memiliki denah rumah dan uang yang paling banyak diantara lawan mainnya.

Materi pembelajaran menggunakan media pembelajaran MGS yang pertama yaitu tentang zat makanan. Tujuan dari pembelajaran ini yaitu siswa dapat mendeskripsikan karbohidrat, protein, lemak dan vitamin yang terkandung pada makanan melalui media pembelajaran MGS. Berdasarkan cara bermainnya, siswa menemukan pengetahuan awal melalui pengulangan materi pada saat putaran pertama. Pada saat bermain, siswa melakukan kegiatan praktikum diantara proses permainan sehingga konsep zat makanan dan uji makanan didapatkan oleh siswa. Proses permainan melalui kegiatan praktikum, siswa dapat mengkonstruk sendiri pemahamannya yang menyebabkan siswa lebih memahami materi yang telah dipelajari. Hal ini sejalan dengan Bruner (1960), yang menyatakan bahwa cara terbaik belajar ialah dengan cara menemukan pemahaman mereka sendiri melalui kegiatan eksperimen (praktikum) atau manipulasi objek secara langsung sehingga proses pembelajaran dapat lebih bermakna.

Materi kegiatan pelaksanaan hampir sama dengan pertemuan pertama atau tidak ada perbedaan cara proses permainan, perbedaannya hanya pada saat materi yang yang dijelaskan berupa organ-organ dan kelainan pada sistem pencernaan. Permainan didalam media pembelajaran MGS ini disajikan gambargambar yang terkait dengan organ pencernaan, dimana siswa akan mengamati dan memberikan jawaban dari kartu soal pada saat permainan sesuai dengan indikator materi. Dengan proses permainan tersebut dapat menstimulus siswa untuk berpikir dalam menemukan jawaban pada kartu soal yang disediakan.

Menurut Jatmika (2005), media visual berupa gambar dapat digunakan untuk membantu menyampaikan materi pembelajaran kepada siswa. Media gambar memiliki kelebihan yaitu dapat dilihat dengan jelas dan dapat menunjukkan materi atau pesan yang disampaikan sehingga mudah dipahami. Setelah selesai permainan, kemudian diadakan diskusi presentasi untuk membahas permainan yang telah dilakukan. Pembahasan materi ini bertujuan untuk memantapkan pemahaman siswa mengenai materi dan menyamakan persepsi mereka tentang materi organ-organ yang mereka pelajari.

Berdasarkan gambar 3 tentang angket respon guru dan siswa dinyatakan 
bahwa respon guru dan siswa berkriteria positif atau sangat setuju, bahwa dengan menggunakan media pembelajaran MGS ini dapat memotivasi, mengurangi kesulitan belajar pada siswa, dan dalam proses keterlaksanaannya siswa lebih mudah memahami materi atau konten yang diberikan. Selain itu, terdapat faktor-faktor lain yang menyebabkan siswa lebih termotivasi yaitu karena siswa dalam kelompok bermainnya semangat dalam mengikuti proses pembelajaran melalui kegiatan permainan menggunakan media pembelajaran MGS sehingga menstimulus siswa yang lainnya juga semangat dalam mengikuti proses pembelajaran. Menurut Wiratmojo dan Sasonohardjo (2002) pemakaian media pembelajaran dalam proses belajar mengajar dapat membangkitkan minat dan keinginan baru, membangkitkan motivasi dan rangsangan kegiatan belajar, dan bahkan membawa pengaruhpengaruh psikologis terhadap pembelajaran. Penggunaan media pembelajaran pada tahap orientasi pengajaran akan sangat membantu keefektifan proses pembelajaran dan penyampaian pesan dan isi pelajaran pada saat itu. Dengan demikian dapat disimpulkan bahwa media pembelajaran adalah sebuah sarana atau informasi pembelajaran yang berguna untuk menunjang proses belajar mengajar agar lebih menarik dan mudah dipahami oleh siswa.

Hasil penelitian yang ditunjukkan pada Tabel 2, terdapat peningkatan pada hasil belajar siswa pada materi sistem pencernaan sebelum diterapkan media pembelajaran dan sesudah diterapkan media pembelajaran. Adanya peningkatan pada nilai tersebut menunjukkan bahwa media pembelajaran MGS mampu mempengaruhi hasil belajar siswa.

Berdasarkan hasil pemaparan di atas, media pembelajaran MGS memiliki kelebihan yang dapat dipaparkan sebagai berikut.

a. Media ini dapat dimainkan lebih dari 5 orang peserta didik. b. Perawatan dan pemeliharaannya dan cara bermainnya relatif mudah.

c. Permainan ini mampu melatih kerjasama antar siswa.

d. Penggunaan media permainan mampu meningkatkan minat dan motivasi siswa untuk mengikuti proses belajar dan merubah pola pikir siswa bahwa belajar bukan hanya terpaku oleh buku mata pelajaran saja.

e. Mengurangi tingkat kebosanan siswa dalam mengikuti proses pembelajaran.

f. Belajar akan lebih efektif bila menggunakan media ini, karena peserta didik akan merasa fun dan antusias dalam mengikuti pembelajaran di kelas.

g. Mampu meningkatkan hasil belajar siswa.

h. Mampu meningkatkan keterampilan siswa dalam kegiatan praktikum.

i. Mampu meningkatkan keaktifan siswa.

Berdasarkan hasil pemaparan di atas, media pembelajaran MGS memiliki kelemahan yaitu menggunakan media pembelajaran MGS harus benar-benar bisa dalam membagi dan memanfaatkan alokasi waktu yang telah disediakan dan harus mampu menguasai kelas yang akan diajar.

\section{Kontribusi Hasil Penelitian}

Hasil penelitian ini dapat digunakan sebagai referensi bagi penelitian lain terkait dengan pengaruh penerapan media pembelajaran Monopoly Games Smart (MGS) terhadap pemahaman konsep siswa. Selain itu dapat digunakan sebagai sarana belajar untuk menambah wawasan, pengetahuan, serta pengalaman mengenai media yang digunakan dalam proses pembelajaran. Adapun 
saran dalam penelitian ini diharapkan guru ataupun peneliti lain dapat mendesain media pembelajaran MGS pada mata pelajaran dan materi pelajaran lain yang bersifat konsep apabila guru ingin meningkatkan pemahaman konsep siswa.

\section{KESIMPULAN}

Berdasarkan hasil yang telah didapatkan, dapat disimpulkan bahwa media pembelajaran Monopoly Games Smart (MGS) berpengaruh terhadap pemahaman konsep siswa kelas VIII materi sistem pencernaan di SMP. Media pembelajaran MGS menyebabkan proses pembelajaran menjadi lebih menarik, dan menyenangkan. Proses pembelajaran pada materi sistem pencernaan juga dirasakan lebih efektif dan berpusat pada siswa yang membuat siswa lebih aktif dalam pembelajaran dan membuat proses belajar menjadi lebih bermakna. Apabila respon pembelajaran baik, maka pemahaman konsep tentang materi juga akan baik.

\section{UCAPAN TERIMA KASIH}

Penulis mengucapkan terima kasih kepada berbagai pihak yang telah membantu dan mendukung dalam pelaksanaan penelitian ini.

\section{DAFTAR PUSTAKA}

Agustiya, F., Ali, S., dan Sri, H. (2017). Influence of CTL Model by Using Monopoly Game Media to The Student's Motivation and Science Learning Outcomes. Journal of Primary Education. 6 (2). 114119.

Bruner, J.S. (1960). The Process of Education. Cambridge: Harvard University Press.
Jatmika, H.M. (2005). Pemanfaatan Media Visual dalam Menunjang Pembelajaran Pendidikan Jasmani di Sekolah Dasar. Jurnal Pendidikan Jasmani Indonesia. 3 (1).

Kemendikbud. (2016). Buku Tematik Terpadu Kurikulum 2013, Buku Kelas IV. Jakarta: Kemendikbud.

Mardia, A dan Andi, F.J. (2017). Efektifitas Penggunaan Media Pembelajaran Monopoli Games Smart Terhadap Minat Belajar Peserta Didik. Jurnal Pendidikan Fisika. 5 (1).

Masruroh, R.D., Puguh, K., dan Meti, I. (2014). Studi Komprasi Pemahaman Konsep Sistem Pernapasan Manusia Melalui Penerapan Pembelajaran Konstruktivisme tipe Novick Dipadu Concept Map dan Ceramah Bervariasi. Bioedukasi. 7 (1). 26-31.

Mulyatiningsih, E. (2013). Metode Penelitian Terapan Bidang Pendidikan. Bandung: Alfabeta.

Murdiyani, I. 2012. Pembelajaran Biologi Menggunakan Metode E-Learning Berbasis Multiple Intelligences pada Materi Sistem Gerak Manusia. Innovative Journal of Curriculum and Educational Technology 1 (1) (2012). ISSN 2252-7125.

Musfiroh, U., Endang, S., dan Nur, K. (2012). Pengembangan Modul Pembelajaran Berorientasi Guided Discovery Pada Materi Sistem Peredaran Darah. BioEdu. 1 (2).

Rustaman, N.Y., Wulan, A.R., dan Yudianto. (2005). Strategi Belajar Mengajar Biologi. Bandung: Jurusan Pendidikan Biologi FPMIPA UPI.

Sajerah. (2013). Penggunaan Model Pembelajaran Cooperative Learning Tipe Think Pair Share (TPS) untuk Meningkatkan Hasil Belajar Siswa Kelas VIII Pada Mata Pelajaran IPA Biologi di 
SMP 4 Parepare Tahun Pelajaran 2009/2010. Bioedukasi. 1 (4).

Siskawati, M., Pargito, dan Pujiati (2016). Pengembangan Media Pembelajaran Monopoli untuk Meningkatkan Minat Belajar Geografi Siswa. Jurnal Studi Sosial. 4 (1).

Subroto, A.G., Bekti, K., dan Djoko, L. (2016). Pemanfaatan Media Monopoli untuk Meningkatkan Keaktifan dan Hasil Belajar IPA Siswa Kelas III SDN Sugihwaras Kecamatan Maospati Kabupaten Magetan Tahun Pelajaran 2015/2016. Jurnal Florea. 3 (2). 49-54.

Suitriani, W. (2016). Penerapan Model Pembelajaran Make a Match dan Media Monopoly Games Smart (MGS) pada Materi Sistem Ekskresi Manusia di MAN Meulaboh-1 Aceh Barat. (Skripsi). Universitas Islam negeri Ar-Raniry Darussalam, Banda Aceh.

Sugiyono. (2015). Metode Penelitian Pendidikan Kombinasi (Mixed Methods). Bandung: Alfabeta.

Susanto, A. (2012). Teori Belajar dan Pembelajaran di Sekolah Dasar. Jakarta: Kencana Prenada Media Group.

Susanto, A., Raharjo., Muji, S.P. (2012). Permainan Monopoli Sebagai Media Pembelajaran Sub Materi Sel Pada Siswa SMA Kelas XI IPA. BioEdu. 1 (1). 1-6.

Thiagarajan dan Semmel. (1974). Pengembangan Media Pembelajaran Interaktif Mata Kuliah Medan Elektromagnetik. Jurnal Edukasi. 5 (1). 11-18.

Ulfa, K. (2017). Penerapan Strategi Pembelajaran PPDP untuk Meningkatkan Penguasaan Konsep dan Kemampuan Berpikir Tingkat Tinggi Siswa SMA pada Materi Fotosintesis. (Tesis).
Universitas Pendidikan Indonesia, Bandung.

Ulfa, K., Anggraini,S., Supriatno, B. (2017). How to Improve the Mastery of Students'Concept on Photosynthesis Topic?. International Conference on Mathematics and Science Education. doi :10.1088/17426596/895/1/012137.

Ulfaeni, S., Husni, W., Henry, J.S. (2017). Pengembangan Media Monergi (Monopoli Energi) untuk Menumbuhkan Kemampuan Pemahaman Konsep IPA Siswa SD. Profesi Pendidikan Dasar. 4 (2). 136-144.

Wijaya, E.Y., Dwi, A.S., dan Amat, N. (2016). Transformasi Pendidikan Abad 21 Sebagai Tuntutan Pengembangan Sumber Daya Manusia di Era Global. Prosiding Seminar Nasional Pendidikan Matematika2016. 1 (16).

Yusuf, A.M. (2015). Asesmen dan Evaluasi Pendidikan. Jakarta: Prenadamedia Group. 